Finanse, Rynki Finansowe, Ubezpieczenia nr 3/2017 (87), cz. 2

\title{
Uchylanie się od opodatkowania podatkiem od towarów i usług - identyfikacja przyczyn zjawiska w Polsce oraz określenie skutków jego występowania
}

\author{
Marta Tomaszewska* \\ Danuta Zawadzka**
}

\begin{abstract}
Streszczenie: $\mathrm{Cel}$ - Zdefiniowanie uchylania się od opodatkowania w świetle istniejących regulacji systemowych, identyfikacja przyczyn tego zjawiska oraz określenie skali jego występowania w Polsce.

Metodologia badania - Badania oparto na kwerendzie literatury z zakresu opodatkowania podatkiem VAT, analizie istniejących uregulowań prawnych dotyczących podatku VAT. Skalę zjawiska uchylania się od opodatkowania określono na podstawie istniejących szacunków luki podatku VAT (Institute for Ad-vanced Studies, PricewaterhouseCoopers).

Wynik - Luka w podatku VAT w Polsce jest relatywnie duża w porównaniu z państwami UE. Jej wielkość wpływa na stan finansów publicznych. W latach 2007-2013 wartość luki była niższa od deficytu sektora finansów publicznych, a w kolejnych latach przewyższyła go. Zmniejszenie różnicy pomiędzy teoretycznymi i rzeczywistymi dochodami z VAT może mieć zatem znaczący wpływ na obniżenie deficytu, a nawet wygenerować nadwyżkę.

Oryginalność/Wartość - Luka w VAT jest podstawowym miernikiem efektywności egzekwowania należności z VAT i przestrzegania wypełniania przez podatników ich obowiązków fiskalnych.
\end{abstract}

Słowa kluczowe: podatek VAT, uchylanie się od opodatkowania, luka podatkowa, budżet państwa

\section{Wprowadzenie}

Obciążenia fiskalne wpływają na kształtowanie sytuacji finansowej podmiotów gospodarczych (Kaczmarzyk, Pyka, 2013, s. 23-24). Ich istnienie skutkuje pomniejszeniem zarówno zasobów pieniężnych, jak i majątku podatnika (Pauch, 2015, s. 635). Mając to na uwadze, przedsiębiorcy często podejmują próby złagodzenia skutków opodatkowania, wpływających negatywnie na wynik ich działalności. Coraz częściej obserwowanym wśród podatników zachowaniem jest realizacja działań, które prowadzą do obniżenia wysokości zobowiązań

\footnotetext{
* Marta Tomaszewska, studentka studiów drugiego stopnia na kierunku Ekonomia na Wydziale Nauk Ekonomicznych Politechniki Koszalińskiej

** dr hab. Danuta Zawadzka prof. PK, Politechnika Koszalińska, Wydział Nauk Ekonomicznych, Katedra Finansów, e-mail: danuta.zawadzka@tu.koszalin.pl
} 
należnych państwu bądź do ominięcia obowiązku podatkowego. W tym celu podmioty wykorzystują zarówno legalne, jak i nielegalne sposoby ucieczki przed podatkiem. Takie zjawisko nasila się wraz z pojawianiem się nowych rozwiązań podatkowych mających przyczynić się do wzrostu świadczeń pieniężnych na rzecz państwa (Walczak, 2008, s. 191). Jednym z takich zjawisk jest uchylanie się od opodatkowania. Jest to działanie sprzeczne z prawem, które prowadzi do minimalizacji obciążenia podatkowego lub jego eliminacji, dzięki działaniom sprzecznym z prawem. W literaturze podkreśla się (Klonowska, 2008, s. 221), że działania te są szkodliwe w co najmniej trzech wymiarach: budżetu państwa (skutkują zmniejszeniem wpływów podatkowych), gospodarki kraju (prowadzą do nieuczciwej konkurencji) oraz życia społecznego (wpływają demoralizująco na innych podatników).

Celem artykułu jest zdefiniowanie uchylania się od opodatkowania w świetle istniejących regulacji systemowych, identyfikacja przyczyn tego zjawiska oraz określenie skali jego występowania w Polsce.

\section{Uchylanie się od opodatkowania jako reakcja na obowiązek podatkowy}

W zależności od rodzaju świadczenia, podatnicy wykazują różnorodne reakcje na opodatkowanie: nielegalne uchylanie się od opodatkowania (oszustwo podatkowe), dostosowanie się do podatku (podatnik uiszcza podatek i nie zmienia swojej działalności), wycofanie się z działalności będącej przedmiotem opodatkowania, legalne uniknięcie podatku, podjęcie działań mających na celu przerzucenie podatku (Pietrasz, 2007, s. 43). Z punktu widzenia problematyki poruszanej w niniejszym opracowaniu, wśród wymienionych sposobów reakcji na obowiązek podatkowy, istotne znaczenie ma uchylanie się od opodatkowania. Zjawisko to różni się od pozostałych przede wszystkim tym, że jest nielegalne, a nieuregulowanie zobowiązania podatkowego, w momencie podjęcia takiej decyzji, pozostaje faktem niejawnym (Bernal, 2008, s. 23). W literaturze ekonomicznej i prawniczej sformułowano wiele definicji omawianego zagadnienia. Według A. Gomułowicza przez uchylanie się od opodatkowania należy rozumieć podejmowanie czynności zakazanych przez prawo podatkowe, prowadzących do minimalizacji obciążeń podatkowych lub całkowitej ich eliminacji (Gomułowicz, 2008, s. 289). Autor podkreśla, że działania te są nielegalne i sprzeczne z literą prawa. M. Żabska definiuje uchylanie się od płacenia podatków jako nielegalne działanie na szkodę Skarbu Państwa, a zatem rodzaj przestępstwa, za które jest przewidziana odpowiedzialność karna. Według autorki zjawisko to jest wręcz defraudacją podatkową, zabiegiem sprzecznym z powszechnie obowiązującymi przepisami prawa (Żabska, 2013, s. 260). A. Bernal zauważa, że do uchylania się od opodatkowania dochodzi wówczas, gdy podatnik w żaden inny sposób nie zrzuci z siebie ciężaru podatkowego (Bernal, 2008, s. 23). Stosując ten rodzaj ucieczki przed zobowiązaniem łamie prawo podatkowe, a zatem dokonuje oszustwa podatkowego (Dolata, 2013, s. 50). Według Komisji Europejskiej uchylanie się od podatku to zachowanie polegające na stosowaniu niezgodnych z prawem mechanizmów, które prowadzą do ukrycia lub pominięcia obowiązku podatkowego. W konsekwencji podatnik płaci mniejszą daninę niż tę, jaką prawnie powinien zapłacić, ukrywając przed władzami podatkowymi osiągnięte 
dochody lub inne informacje (Walka z oszustwami..., s. 1). Z kolei oszustwo podatkowe Komisja Europejska definiuje jako formę umyślnego uchylania się od opodatkowania, które podlega karze przewidzianej przepisami prawa karnego, zatem obejmuje działania polegające na umyślnym składaniu fałszywych deklaracji podatkowych lub sporządzaniu fałszywych dokumentów (Walka z oszustwami..., s. 1).

Istnieje wiele form uchylania się od opodatkowania. J. Szlęzak-Matusewicz wymienia kilka sposobów, które w tym celu wykorzystują podatnicy: zatajenie źródeł przychodów, nierejestrowanie działalności gospodarczej (działalność w szarej strefie), fałszowanie ksiąg podatkowych, naruszanie zakazów i nakazów prawnych, zaliczanie w ciężar kosztów wydatków, które nie zostały poniesione, wystawianie fikcyjnych faktur (Szlęzak-Matusewicz, 2013, s. 16). Obok wymienionych wyżej metod ucieczki przed podatkiem, A. Gomułowicz zalicza do takich również: niezgłoszenie obowiązku podatkowego, odliczenie ulg z tytułów nieprzysługujących podatnikowi, odliczenie amortyzacji od nieistniejących środków trwałych, fikcyjny eksport (Gomułowicz, 2008, s. 289). Według R. Sowińskiego uchylaniem się od opodatkowania będą zarówno zaniechania podatnika, jak i jego działania - w tym „agresywne” sposoby uchylania się od podatku, np. wyłudzenie zwrotu podatku od towarów i usług (Sowiński, 2009, s. 15). K. Wojtowicz-Janicka, określając sposoby uchylania się od opodatkowania, powołuje się na przepisy prawa karnego skarbowego, które kwalifikują czyny zabronione jako przestępstwa lub wykroczenia skarbowe, a za ich popełnienie przewidziane są określone sankcje. Przedsiębiorca podlega tym karom, jeżeli m.in.: uchyla się od opodatkowania przez nieujawnienie podmiotu lub przedmiotu opodatkowania, bądź niezłożenie deklaracji podatkowej, prowadzi księgi w sposób nierzetelny, nie wystawia faktur i rachunków, wystawia je nierzetelnie lub posługuje się takimi dokumentami, dokonuje sprzedaży z pominięciem kasy fiskalnej, dopuszcza się wyłudzenia zwrotu VAT (Wojtowicz-Janicka, 2012, s. 20). Według J. Dużego należy dostrzec różnice między zjawiskiem uchylania się od opodatkowania a przestępczym nadużyciem mechanizmów podatkowych. Autor wyjaśnia, że uchylanie się od podatku, nawet jeśli zostało dokonane w drodze oszustwa podatkowego, wiąże się z redukowaniem ciężaru podatkowego przez podatnika prowadzącego realną działalność gospodarczą. Głównym motywem znacznej części podatników naruszających przepisy prawa podatkowego np. poprzez dokonanie oszukańczego procederu fałszowania faktur, czy też oszustwa w związku ze składaniem nieprawdziwych deklaracji podatkowych, nie jest zaś obniżenie czy eliminacja obciążeń fiskalnych. Wykorzystują oni mechanizmy podatkowe, aby osiągnąć bezpodstawne korzyści kosztem mienia Skarbu Państwa. Zdaniem J. Dużego tego typu zabiegi wykraczają poza zjawisko uchylania się od opodatkowania. Ich sprawcy bowiem nie ukrywają przed organem podatkowym prawdziwego zakresu stanów faktycznych objętych opodatkowaniem, ale kreują fikcyjną rzeczywistość gospodarczą w celu osiągnięcia zysków. Taki proceder przynosi dużo większe straty budżetowe, niż w przypadku uchylania się od podatków (Duży, 2013, s. 28-30).

Rozważając problematykę uchylania się od podatku, należy podkreślić, że pojęcie to jest często błędnie utożsamiane z optymalizacją podatkową oraz unikaniem opodatkowania. Optymalizacja podatkowa to „przemyślana polityka podatkowa przedsiębiorstwa, której celem jest efektywne zmniejszenie obciążeń fiskalnych firmy. W praktyce polega na ona 
przyjęciu takich prawnie dozwolonych rozwiązań, które umożliwią zminimalizowanie wysokości płaconych przez przedsiębiorstwo podatków lub odpowiednie rozłożenie ich w czasie" (Spoz, 2012, s. 237). Do legalnych działań mieszczących się w zakresie optymalizacji podatkowej M. Żabska zalicza m.in.: planowanie podatkowe, oszczędzanie podatkowe i unikanie opodatkowania (Żabska, 2013, s. 261). W literaturze unikanie opodatkowania jest postrzegane jako działanie polegające na wykorzystywaniu luk w prawie oraz wątpliwości interpretacyjnych, a także na dokonywaniu transakcji, które w sztuczny sposób prowadzą do obniżenia zobowiązania podatkowego należnego państwu czy też zwolnienia od opodatkowania. Czynności takie zawsze są przeprowadzane w granicach obowiązującego prawa (Wyrzykowski, 2015, s. 42). Mogą one przybierać następujące formy: wykorzystanie możliwości tkwiących w systemie podatkowym, wykorzystanie luk w prawie podatkowym, przeniesienie działalności powodującej powstanie obowiązku podatkowego do innego państwa, charakteryzującego się niższym opodatkowaniem, zaprzestanie działalności podlegającej opodatkowaniu lub rezygnacja z wartości materialnych objętych określonym podatkiem (Dolata, 2013, s. 49). Według ustawodawcy unikanie opodatkowania to sytuacja, w której podatnik, podejmując w sztuczny sposób określone działanie, kieruje się przede wszystkim zamiarem osiągnięcia korzyści podatkowej, niezgodnej w danych okolicznościach z przedmiotem i celem przepisów ustawy podatkowej (Ustawa, 1997, art. 119a, § 1). Tak rozumiane unikanie opodatkowania jest zjawiskiem sprzecznym z przepisami prawa i nie jest pożądane z uwagi na interes budżetowy państwa.

Warto zauważyć, że uchylanie się od podatku oraz unikanie opodatkowania to zjawiska współistniejące w polskim systemie podatkowym, a wyznaczenie wyraźnej granicy pomiędzy tymi działaniami nie jest łatwym zadaniem. Łączy je bowiem dążenie do maksymalizacji korzyści osoby zobowiązanej do zapłacenia podatku. Oba rodzaje działań prowadzą do uszczuplenia dochodów budżetu państwa (Pasternak-Malicka, 2013b, s. 57), są ponadto negatywnie postrzegane przez ustawodawcę i objęte restrykcjami prawnymi. Przy rozróżnianiu tych zjawisk należy dlatego wziąć pod uwagę następujące czynniki: motywy działania podatnika, fikcyjny charakter działania podatnika, rozmiary korzyści uzyskanych w związku z uchylaniem się od podatku, ocenę kompetentnych władz (Filip, 2009, s. 369, za: Głuchowski, 2005, s. 150). Pod względem społecznym i gospodarczym uchylanie się od podatku jest działaniem niewątpliwie bardziej szkodliwym. Uchylanie się od opodatkowania jest identyfikowane również z innymi terminami o zbliżonym charakterze, takimi jak: przestępstwo i wykroczenie skarbowe, szara strefa, czy pranie brudnych pieniędzy. Tymczasem istota tych pojęć jest różna (Bernal, 2008, s. 29).

Rozpatrując problematykę uchylania się od opodatkowania, warto zwrócić uwagę, że jednoznaczne zdefiniowanie problemu nie jest łatwym zadaniem. Głównym powodem trudności jest to, że zakres działań kwalifikowanych pod pojęciem uchylania się od opodatkowania jest bardzo rozległy. W reakcji na działania podejmowane przez państwo w celu ograniczania omawianego zjawiska, powstają nowe metody ucieczki przed podatkiem, a istniejące są wciąż „udoskonalane”. 


\section{Przyczyny uchylania się od opodatkowania}

Zjawisko uchylania się od podatku jest procesem złożonym. Ta złożoność wynika z tego, że przyjęcie przez podatnika określonej postawy wobec opodatkowania zależy od różnorodnych czynników, zarówno wewnętrznych - odnoszących się do podatnika (świadomość podatkowa, moralność podatkowa, brak akceptacji dla władz publicznych, skłonność podatnika do ryzyka, sytuacja ekonomiczna podatnika, czynniki demograficzne), jak i zewnętrznych wynikających z otoczenia (niska jakość dóbr publicznych, wysokość obciążeń podatkowych, wysokość sankcji i kar, wysokie koszty poboru podatku, złożoność systemu podatkowego, skuteczność organów administracji skarbowej, skala zjawiska uchylania się od opodatkowania i korupcji w gospodarce, nastawienie urzędników do podatników) (Leoński, 2013, s. 158). W literaturze dotyczącej podatków najczęściej wskazuje się trzy grupy przyczyn występowania zjawiska nielegalnej ucieczki przed opodatkowaniem (Sowiński, 2009, s. 22): ekonomiczne, społeczne i demograficzne. Ekonomicznych przyczyn omawianego zjawiska upatruje się głównie w wymiarze obciążeń podatkowych, które łączy się z wpływami do budżetu państwa z tego tytułu (krzywa Laffera). Powodem uchylania się od opodatkowania może być również niska surowość kary za tego typu postępowanie (Niesiobędzka, 2013, s. 29). W celu podniesienia dyscypliny podatkowej zarówno ustawodawca, jak i organy stosujące prawo podatkowe, często są skłonni do zwiększania liczby kontroli i podwyższania wysokości sankcji. Tymczasem zaostrzenie kar nie tylko może nie przynieść oczekiwanych efektów, ale również może nasilać wśród podatników niechęć do ponoszenia obowiązkowych świadczeń na rzecz państwa (Niesiobędzka, 2013, s. 29-30). Społeczne przyczyny uchylania się od opodatkowania wiążą się z poczuciem sprawiedliwości systemu podatkowego, rozpatrywanej w kilku wymiarach: wymiennej, horyzontalnej, wertykalnej, proceduralnej (Pasieczna, 2011, s. 461; Sowiński, 2009, s. 110, 114-115; Sowiński, 2012, s. 7; Niesiobędzka, 2013, s. 73-74). Jako społeczny czynnik determinujący poziom omawianego zjawiska wymienia się również mentalność podatkową, czyli postawę wobec obciążeń fiskalnych reprezentowaną przez określoną grupę społeczną (Pasternak-Malicka, 2013a, s. 8). Podatnik, należący do danego zgrupowania, postępuje w taki sposób, jaki w określonych okolicznościach jest akceptowany przez pozostałych członków zbiorowości. Zatem nie będzie on przestrzegał przepisów prawa podatkowego, jeżeli inne osoby ich nie przestrzegają (Gomułowicz, 2008, s. 275). Wzrostowi zjawiska uchylania się od opodatkowania sprzyjają również czynniki demograficzne, takie jak m.in.: wiek, rozwój moralny, płeć i wykształcenie podatnika, choć podkreśla się, iż badania w tym zakresie są dość trudne do przeprowadzenia (Pasieczna, 2011, s. 463).

\section{Skala uszczupleń dochodów budżetowych z tytułu podatku VAT}

Skala uszczupleń dochodów podatkowych państwa jest prezentowana w postaci luki podatkowej, którą należy rozumieć jako różnicę między podatkiem faktycznie zapłaconym 
i podatkiem, który powinien być uiszczony, gdyby wszyscy podatnicy w prawidłowy sposób zadeklarowali wykonane czynności i transakcje, zgodnie z literą prawa i intencją prawodawcy (Novysedlak, Palkovicova, 2012, s. 7; por. Straty..., 2013, s. 5). Na podstawie przytoczonej definicji luki podatkowej, można zatem określić, że luka związana z podatkiem VAT stanowi różnicę między oczekiwanymi dochodami z VAT, gdyby wszystkie zobowiązania z tytułu tego podatku były uregulowane, a rzeczywistymi wpływami z VAT, pobranymi przez dane państwo członkowskie'. Należy podkreślić, że luka w VAT jest zjawiskiem złożonym, a oszustwa podatkowe, w tym uchylanie się od VAT, są istotną, jednak nie jedyną jej częścią składową. Występowanie i rozmiary tej luki determinuje bowiem wiele czynników, których dokładne określenie jest trudne - obejmują one m.in.: 1) działalność gospodarczą podatników, wykonywaną w ukryciu przed aparatem skarbowym, taką jak: szara strefa (działalność pozostającą w zgodzie z przepisami prawa, od której jednak nie jest odprowadzana należna kwota podatku), oszustwa podatkowe (działalność skierowaną głównie na uzyskanie korzyści majątkowych poprzez nieodprowadzenie należnej kwoty podatku); 2) działalność mającą na celu wyłącznie obniżenie wysokości zobowiązania za pomocą legalnych środków prawnych, lecz w sposób niezgodny z intencją prawodawcy przez optymalizację podatkową; 3) brak wydajności aparatu skarbowego w kontroli i poborze należnych podatków, które zostały mu ujawnione; 4) uchybienia w samowymiarze podatku niewychwycone przez aparat skarbowy; 5) podatek nieodprowadzony z powodu upadłości podatników VAT (Straty..., 2013, s. 5-6).

Warto zaznaczyć, że luka w VAT w Polsce jest relatywnie duża w porównaniu do państw Unii Europejskiej (rys. 1). Na tle regionu niższą niż w Polsce luką w VAT cechują się Niemcy, Czechy i Węgry, wyższą natomiast - Słowacja, Litwa i Rumunia.

W 2014 roku najniższą lukę w VAT odnotowano w Szwecji (1\%), Luksemburgu (4\%) i Finlandii (7\%). Najwyższą lukę natomiast zaobserwowano w Rumunii (38\%), Litwie (37\%) i na Malcie (35\%). Na wykresie nie uwzględniono Cypru, z powodu braku danych po aktualizacji rachunków narodowych Eurostatu. Chociaż polska luka nie jest największa w Unii Europejskiej, bo wynosi 24\%, to jednak jest ponad dwukrotnie wyższa od unijnej mediany i o 8 p.p. od średniej arytmetycznej². Analizując wyniki raportu, przygotowanego przez Instytut Badań Zaawansowanych na zlecenie Dyrekcji Generalnej ds. Podatków i Unii Celnej, należy wskazać, że zwiększenie dochodów z tytułu podatku od towarów i usług w Polsce w latach 2013-2014 przyczyniło się do zmniejszenia różnic w VAT w ujęciu względnym i bezwzględnym (rys. 2).

1 http://europa.eu/rapid/press-release_MEMO-13-800_en.htm (21.01.2017).

2 Średnia arytmetyczna wartości luki podatkowej w VAT w 2014 r. wszystkich państw należących do UE, z wyjątkiem Cypru, z powodu braku danych po aktualizacji rachunków narodowych Eurostatu. 


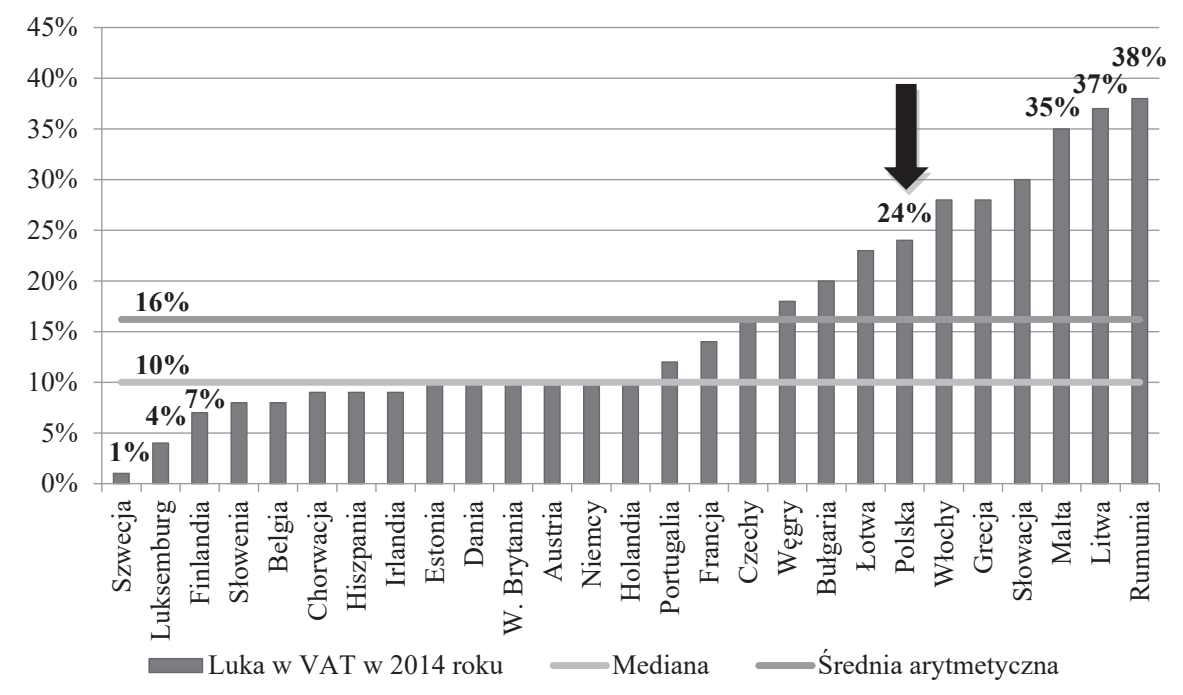

Rysunek 1. Luka w VAT jako procent teoretycznych dochodów z tytułu VAT państw należących do Unii Europejskiej w 2014 roku - według Instytutu Badań Zaawansowanych Źródło: opracowanie własne na podstawie: Study and Reports... (2016, s. 16).

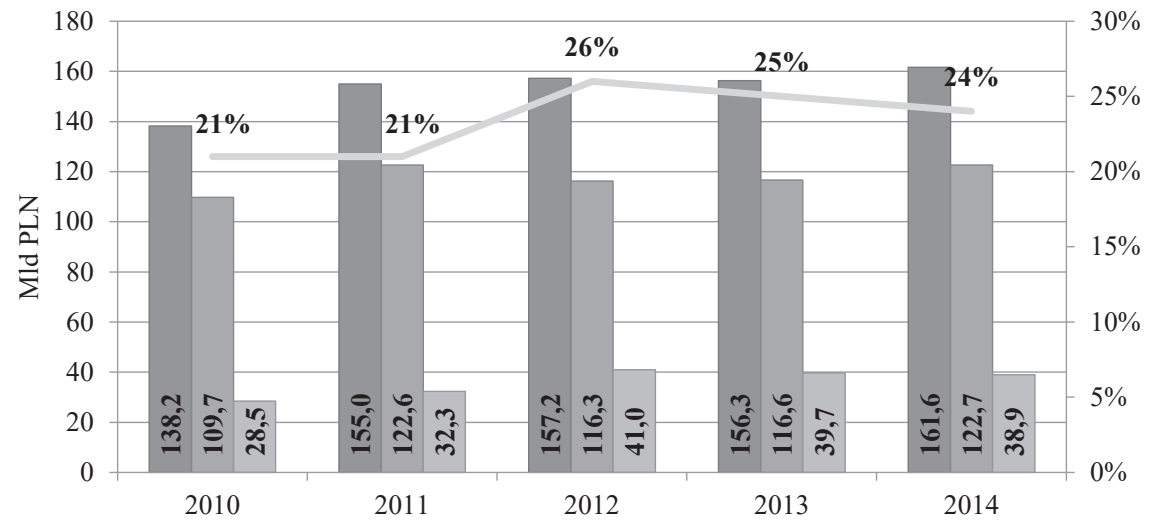

Teoretyczne dochody z VAT

Rzeczywiste dochody z VAT

Luka w VAT

Luka w VAT jako procent teoretycznych dochodów z VAT

Rysunek 2. Teoretyczne i rzeczywiste dochody z VAT oraz luka w VAT w Polsce w latach 20102014 według szacunków Instytutu Badań Zaawansowanych

Źródło: opracowanie własne na podstawie: Study and Reports... (2016, s. 43). 
Od 2012 roku luka w VAT zmniejszyła się o około 2 mld zł i 2 p.p. planowanych dochodów z tego podatku. Sytuacja ta zbiegła się z podjęciem skutecznych działań polskiego rządu w kierunku poprawy zarówno przestrzegania przez podatników przepisów obowiązującego prawa, jak i skuteczności ich egzekwowania (Study and Reports..., 2016, s. 16).

$\mathrm{Z}$ uwagi na różnice $\mathrm{w}$ metodach szacowania luki podatkowej, nieco inaczej prezentują się wyliczenia firmy doradczej PricewaterhouseCoopers (rys. 3).

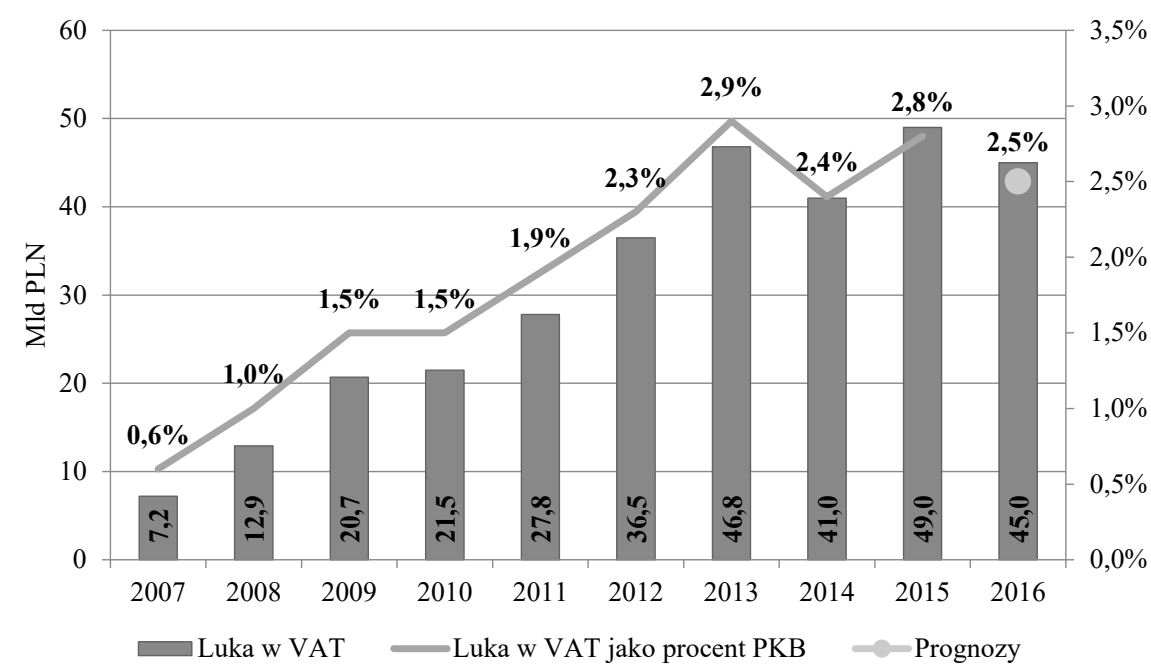

Rysunek 3. Luka podatkowa w VAT w Polsce w latach 2007-2016 według wyliczeń i prognoz PricewaterhouseCoopers

Źródło: opracowanie własne na podstawie: Wytudzenia VAT... (2016, s. 5); Luka podatkowa w VAT... (2014, s. 5).

Według obliczeń PwC, w przeciwieństwie do szacunków Instytutu Badań Zaawansowanych, w 2013 roku zanotowano w Polsce wzrost luki w VAT o około 10,3 mld zł. Spadek luki natomiast zaobserwowano dopiero w 2014 roku. Wówczas zmniejszyła się ona o ponad 6 mld zł. Działania, które przyniosły efekt to m.in.: zwiększenie publicznej świadomości zjawiska, nowe rozwiązania legislacyjne, lepsza analityka i planowanie kontroli, poprawa współpracy organów państwa (Wytudzenia VAT..., 2015, s. 7). Warto zauważyć, że w 2015 roku ponownie wzrosła wartość luki podatkowej o około 8 mld zł. Rozwiązania wdrożone w 2014 roku okazały się bowiem niewystarczające. Biorąc jednak pod uwagę legislacyjne działania rządu (już wdrożone oraz te w trakcie realizacji), zakłada się zmniejszenie luki w VAT. Jedną z przyczyn optymistycznych prognoz jest determinacja Ministerstwa Finansów w uszczelnianiu systemu podatkowego, poparta dodatkowo konkretnymi działaniami (Wytudzenia VAT..., 2016, s. 8-10).

Analizując problem luki w VAT warto porównać jej wysokość z deficytem sektora finansów publicznych, jaki Polska notowała w latach 2007-2015 (rys. 4). 


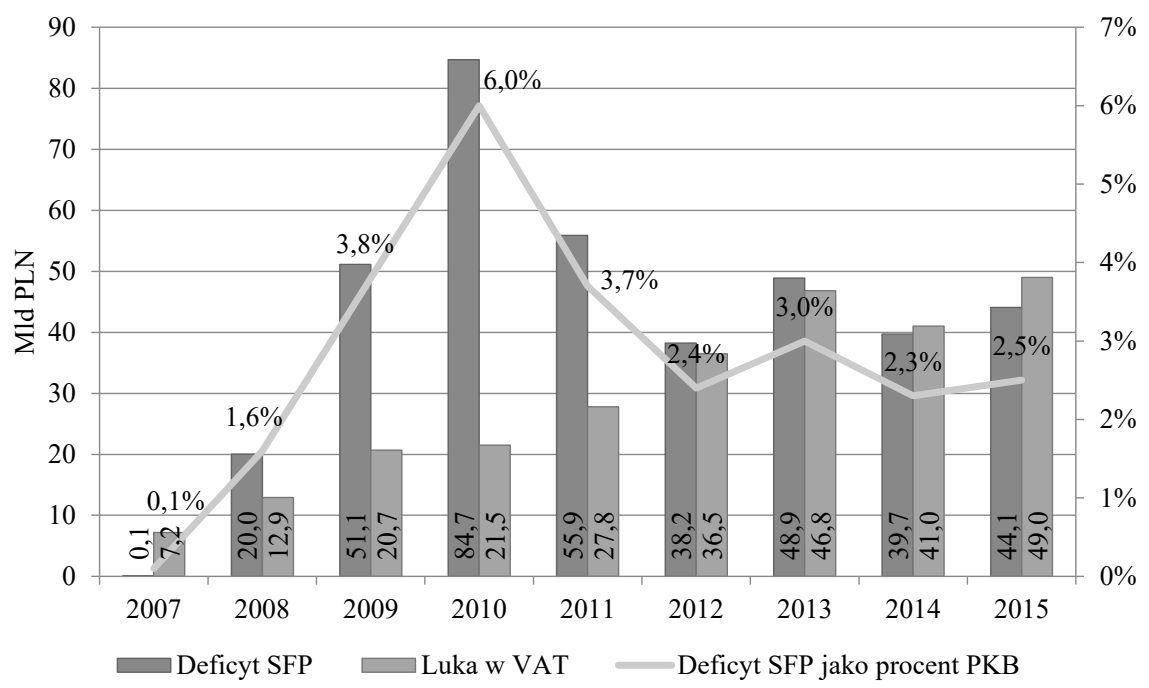

Rysunek 4. Wysokość deficytu sektora finansów publicznych według Ministerstwa Finansów i luki w VAT według PricewaterhouseCoopers w Polsce w latach 2007-2015

Źródło: opracowanie własne na podstawie: Sprawozdania z wykonania budzetu państwa w 2007 r. (2008, 2009, 2010, 2011, 2012, 2013, 2014, 2015); Wyludzenia VAT... (2016, s. 5); Luka podatkowa w VAT... (2014, s. 5).

Z rysunku 4 wynika, że w badanym czasie deficyt sektora finansów publicznych znacznie się wahał, co wynikało z niestabilnej koniunktury gospodarczej, szczególnie światowego kryzysu finansowego, a także zmian w polityce fiskalnej państwa (Baran, Sawulski, 2016, s. 18). Jedynie w 2007 roku odnotowano nadwyżkę na poziomie $0,1 \mathrm{mln} \mathrm{zl}$, co stanowiło $0,1 \%$ PKB. W tym czasie luka w VAT była najmniejsza. Najwyższy deficyt dotyczył 2010 roku. Rok wcześniej Polska została objęta przez Radę Unii Europejskiej procedurą nadmiernego deficytu. Od 2011 roku sytuacja związana z finansami publicznymi zaczęła się stabilizować, a w 2015 roku Rada Unii Europejskiej zniosła procedurę nadmiernego deficytu wobec Polski. Nie ulega wątpliwości, że wzrost luki związanej z podatkiem VAT znacząco wpłynął na stan finansów publicznych w Polsce. W latach 2007-2013 wartość luki była niższa od deficytu sektora finansów publicznych, a w kolejnych latach przewyższyła już jego wysokość. Zmniejszenie różnicy pomiędzy teoretycznymi i rzeczywistymi dochodami z VAT może znacząco wpływać na obniżenie deficytu, a nawet wygenerować nadwyżkę. Luka w VAT jest podstawowym miernikiem efektywności egzekwowania należności z VAT i przestrzegania wypełniania przez podatników ich obowiązków fiskalnych (Tratkiewicz, 2016, s. 186). Jej niepokojąco rosnący trend sygnalizuje zatem konieczność rzetelnej oceny skuteczności aparatu skarbowego w tym obszarze. 


\section{Uwagi końcowe}

W literaturze brakuje zgodności co do sposobu, w jaki należy definiować uchylanie się od opodatkowania. Podobnie w prawie podatkowym nie została sformułowana legalna definicja tego pojęcia. Do pomiaru uszczupleń dochodów podatkowych służy analiza wartości luki podatkowej. Według obliczeń PwC w 2007 roku wartość luki w podatku VAT wynosiła 7,2 mld zł, a w 2015 roku luka osiągnęła poziom 49 mld zł. Szacuje się, że w 2016 roku różnica pomiędzy potencjalnymi i faktycznymi dochodami z tego podatku stanowiła wartość 45 mld zł. Od 2014 roku wartość luki przewyższa deficyt sektora finansów publicznych. Sytuacja ta pokazuje, jak istotne znaczenie w zapewnieniu stabilnych wpływów z VAT odgrywa skuteczność metod zwalczania nadużyć w tym podatku.

\section{Literatura}

Baran, J., Sawulski, J. (2016). Z dala od równowagi - ewolucja finansów publicznych w Polsce w latach 2004-2014. IBS Policy Paper, 3.

Bernal, A. (2008). Zjawisko uchylania się od podatków dochodowych i metody jego ograniczania. Warszawa: Difin.

Dolata, S. (2013). Podstawy wiedzy o polskim systemie podatkowym, (wyd. 3). Warszawa: Wolters Kluwer.

Duży, J. (2013). Zorganizowana przestępczość podatkowa w Polsce. Zwalczanie przestępnego nadużycia mechanizmów podatków VAT i akcyzowego. Warszawa: Wolters Kluwer.

Filip, P. (2009). Planowanie finansowe a optymalizacja obciążeń fiskalnych działalności gospodarczej. Nierówności społeczne a wzrost gospodarczy. Uwarunkowania instytucjonalne, 15, za: Głuchowski J. (2005). Polskie prawo podatkowe. Warszawa: LexisNexis.

Gomułowicz, A. (2008). Postawy wobec opodatkowania. W: A. Gomułowicz, J. Małecki, Podatki i prawo podatkowe (wyd. IV) (s. 259-268). Warszawa: LexisNexis.

http://europa.eu/rapid/press-release_MEMO-13-800_en.htm (21.01.2017).

Kaczmarzyk, J., Pyka, A. (2013). Uwarunkowania działalności finansowej przedsiębiorstw. W: B. Ciupek, T. Famulska (red.), Strategie podatkowe przedsiębiorstw (s. 23-24). Katowice: Wydawnictwo Uniwersytetu Ekonomicznego w Katowicach.

Klonowska, A. (2008). Ekonomiczne skutki ucieczki przed podatkiem. Zeszyty Naukowe Uniwersytetu Ekonomicznego $w$ Krakowie, 778, 221.

Leoński, W. (2013). Zjawisko uchylania się od opodatkowania w grupach społeczno-zawodowych. Zeszyty Naukowe Wydziału Nauk Ekonomicznych Politechniki Koszalińskiej, 17, 157-167.

Niesiobędzka, M. (2013). Dlaczego nie płacimy podatków. Psychologiczna analiza uchylania się od opodatkowania. Warszawa: Wydawnictwo Naukowe Scholar.

Novysedlak, V., Palkovicova, J. (2012). The estimate of the value added tax revenue loss. Institute for Financial Policy (IFP), The Ministry of Finance of the Slovak republic, March 2012, s. 7.

Pasieczna, E. (2011). Przyczyny zjawisk unikania i uchylania się od opodatkowania. Rachunkowość a controlling. Prace Naukowe Uniwersytetu Ekonomicznego we Wrocławiu, 181, 457-466.

Pasternak-Malicka, M. (2013a). Mentalność i moralność podatkowa a reakcje gospodarstw domowych na obowiązek podatkowy. Modern Management Review, 18, (20/1).

Pasternak-Malicka, M. (2013b). Przeciwdziałanie unikaniu i uchylaniu się od opodatkowania w Unii Europejskiej. Humanities and Social Sciences, 18 (20/1), 55-67. 
Pauch, D. (2015). Problem oszustw podatkowych na przykładzie podatku VAT. Zeszyty Naukowe Uniwersytetu Szczecińskiego, 848. Ekonomiczne Problemy Ustug, 116, 635.

Pietrasz, P. (2007). Opodatkowanie dochodów nieujawnionych. Warszawa: Wolters Kluwer.

Sowiński, R. (2009). Uchylanie się od opodatkowania. Przyczyny, skutki i sposoby zapobiegania zjawisku. Poznań: Wydawnictwo Naukowe Uniwersytetu Adama Mickiewicza w Poznaniu.

Sowiński, R. (2012). Dlaczego podatnicy uchylają się od opodatkowania? Przeglą Ekonomiczny, 5.

Spoz, A. (2012). Wybrane metody optymalizacji podatkowej przedsiębiorstw. Zeszyty Naukowe Uniwersytetu Szczecińskiego, 708. Finanse, Rynki Finansowe, Ubezpieczenia, 52, 237-146.

Straty Skarbu Państwa w VAT. Pobrane z: https://www.pwc.pl/pl/publikacje/assets/pwc_straty_skarbu_panstwa_w_vat.pdf, s. 5 (27.05.2013).

Study and Reports on the VAT Gap in the EU-28 Member States: 2016 Final Report (2016). Warszawa: Institute for Advanced Studies.

Szlęzak-Matusewicz, J. (2013). Zarządzanie podatkami osób fizycznych. Warszawa: Wolters Kluwer.

Tratkiewicz, T. (2016). Luka w VAT - sposoby przeciwdziałania w Polsce i Unii Europejskiej. Zeszyty Naukowe Uniwersytetu Ekonomicznego w Katowicach, 94.

Ustawa z dnia 29 sierpnia 1997 roku Ordynacja podatkowa, t.j. Dz.U. z 2017 r., poz. 201, z późn. zm., Art. 119a, § 1.

Walczak, B. (2008). Reakcje podatników na obowiązek podatkowy. W: L. Dorozik, J. Stanielewicz, B. Walczak, System podatkowy Polski (s. 191-198). Szczecin: Polskie Towarzystwo Ekonomiczne Oddział Wojewódzki w Szczecinie.

Walka z oszustwami podatkowymi i uchylaniem się od opodatkowania. Sprawy przedłożone przez Komisję na posiedzeniu Rady Europejskiej w dniu 22 maja 2013 r. Komisja Europejska. Pobrane z: http://ec.europa.eu/ europe2020/pdf/tax_pl.pdf, s.1 (28.10.2016).

Wojtowicz-Janicka, K. (2012). Optymalizacja podatkowa w doktrynie i orzecznictwie. W: Ł. Mazur (red.), Optymalizacja podatkowa. Warszawa: Wolters Kluwer.

Wyludzenia VAT - luka podatkowa w 2014 r. i prognoza na 2015 r. (2015). PricewaterhouseCoopers.

Wyludzenia VAT - luka podatkowa w 2015 r. i prognoza na 2016 r. (2016). PricewaterhouseCoopers.

Wyrzykowski, W. (2015). Optymalizacja podatkowa przedsiębiorców - granice prawa a granice bezpieczeństwa. Zarzadzanie i Finanse, 3 (2), 35-50.

Żabska, M. (2013). Optymalizacja podatkowa a oszustwa podatkowe. Zeszyty Naukowe Uniwersytetu Szczecińskiego, 765. Finanse, Rynki finansowe, Ubezpieczenia, 61.

\title{
VALUE ADDED TAX EVASION - IDENTYFYING THE CAUSES OF PHENOMENON IN POLAND AND DETERMINIG THE EFFECTS OF ITS OCCURANCE
}

\begin{abstract}
Purpose - Defining tax evasion in the light of existing system regulations, identifying the causes of this phenomenon and determining the scale of its occurrence in Poland.

Design/Methodology/approach - The study was based on a literature survey on VAT, an analysis of existing VAT regulations. The scale of the tax evasion phenomenon is based on existing estimates of the VAT gap (Institute for Advanced Studies, PricewaterhouseCoopers).

Findings - The VAT gap in Poland is relatively large compared to EU countries. Its size influences the state of public finances. In the years 2007-2013 the gap was lower than the deficit of the public finance sector and in the following years it exceeded its value. Reducing the gap between theoretical and real VAT revenues can thus have a significant impact on deficit reduction and even a surplus.

Originality/value - The VAT gap is a fundamental measure of the efficiency of enforcement of VAT charges and the compliance of taxpayers with their fiscal obligations.
\end{abstract}

Keywords: VAT, evasion from taxation, tax gap, country budget

\section{Cytowanie}

Tomaszewska, M., Zawadzka, D. (2017). Uchylanie się od opodatkowania podatkiem od towarów i usług - identyfikacja przyczyn zjawiska w Polsce oraz określenie skutków jego występowania. Finanse, Rynki Finansowe, Ubezpieczenia, 3 (87/2), 41-51. DOI: 10.18276/frfu.2017.87/2-04. 